\title{
Mexico's MBA Programs: Seven Years Into NAFTA
}

Rutilio Martinez, (E-mail: rutilio.martinez@unco.edu), University of Northern Colorado

\begin{abstract}
In its first seven years the North American Free Trade Agreement, NAFTA, has generated growth and stability for the Mexican economy. As a result of this success, the demand for academically trained managers increased and enrollment in MBA programs almost quadrupled. Despite this remarkable growth in enrollment, the total student population in MBA programs is relatively small and their academic standards are rather low. It is expected, however, that as NAFTA and other similar treaties continue modernizing Mexico's economy, the academic standards will rise and enrollment will be in proportion to the size of the economy.
\end{abstract}

\section{Introduction}

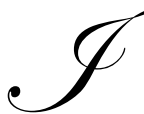

n 1980 Mexico's economy was going through a boom fueled by oil revenues. Despite this bonanza competition was absent from most markets; high-tariffs and other import restrictions protected domestic producers from foreign competition; the private sector was in-ward looking; most sectors were excessively regulated; technological backwardness prevailed; the government subsidized crucial industrial inputs like electricity, and most labor markets had huge surpluses. In this environment firms had little, if any, need for academically well-trained managers. This was reflected in the quantity and quality of the MBA programs. In 1980 there were 23 MBA programs in the nation with an enrollment of 3,533 students (ANUIES 1981). In all but one of these programs research was totally neglected, and adjunct professors, who lacked advanced degrees in business related areas, formed the faculty.

The boom came to an abrupt end in August of 1982 when Mexico was unable to pay the interest on its $\$ 100$ billion foreign debt and the economy collapsed. This event signaled to Mexico's governments that it was time to start adopting policies that promoted the formation of a market-oriented economy. This process of economic liberalization began in 1985 and advanced slowly until 1994 when it underwent a rapid acceleration as a result of the implementation of the North American Free Trade Agreement, NAFTA. Today, Mexico's economy is one of the most open in the world; it is export oriented; subsidies have been cut drastically, and labor surpluses have shrunk considerably. This economic modernization has not been, however, accompanied by a significant improvement of the nation's MBA programs. At the end of 2000 the quality of the programs was practically the same as it was in 1980 and the total population in graduate business programs exceeded 24,000 students (ANUIES 2001), still a miniscule enrollment for a $\$ 600$ billion economy.

This paper discusses possible causes for the small enrollment in MBA programs and the stagnation of their quality in Mexico's NAFTA-driven economy. The discussion is primarily based upon information gathered in interviews with senior faculty from three leading business schools.

The paper is organized as follows. The next section briefly discusses the evolution of Mexico's MBA programs. The third section describes possible explanations for the stagnation in enrollment and in the quality of these programs. The fourth section discusses the connection of this stagnation with Mexico's management culture and few possible implications for foreign executives who enter Mexico's business environment. The fifth section contains conclusions.

Readers with comments are questions are encouraged to contact the author via email. 


\section{Mexico's MBA Programs: 1967-2001}

The Instituto Panamericano de Alta Dirección de Empresa, the IPADE, was established in 1967. The IPADE housed Mexico's first MBA. It started with approximately 30 students. Originally, a two-year full time program was the only option offered. Later, in the seventies, the IPADE would also offer a part-time MBA for working executives. Both programs have followed the case method, with IPADE's own faculty being responsible for writing the cases. Since its foundation, the IPADE has been very selective and has had formal links with the Harvard Business School (IPADE 2002). The program has also emphasized the need for professionalism in the management of Mexico's firms, the unavoidable internationalization of the nation's economy and the social obligations of the business enterprise. Currently enrollment in the two programs is about 200 students (IPADE 2002).

Mexico's second MBA program was established in 1973 by the Instituto Tecnológico y de Estudios Superiores de Monterrey, the ITSEM. In this year the ITESM established an executive MBA program in two locations: one in its Monterrey campus and the other in a building explicitly built for this purpose in downtown Mexico City. The program then, as now, was aimed at executives who wanted to acquire a management education, but who were unable or unwilling to devote full-time to this endeavor. In the late 1970s, the ITSEM started to offer its executive MBA program in other cities. Currently, the ITSEM's executive MBA is offered in 16 different locations and enrolls close to 4,000 students or about 16\% of all MBA students in Mexico (ANUIES 2001).

During the late 1970s and early 1980s, following the lead of the ITSEM, other private and public institutions established their own programs. Thus, by 1981 there were 4,727 MBA students enrolled in 27 programs offered on 34 campuses. Eight of these campuses belonged to the ITSEM, 15 to other private institutions, and 11 to public universities (ANUIES 1982).

From 1981 to 1993, the year before NAFTA was implemented, enrollment grew a total of 1,637 students (ANUIES 2000). One possible reason for the insignificant grow in MBA enrollments during these 12 years was the sluggish growth of Mexico's economy during the 1980s, "the lost decade."

The implementation of NAFTA and the accompanying free market policies were expected to cause the expansion of many markets and to intensify competition in them. NAFTA and related policies were, therefore, expected to increase the demand for qualified managers. Thus, as NAFTA and the accompanying free market policies were implemented, both enrollment in MBA programs and the quality of these programs across the nation were also expected to undergo very noticeable increases.

During NAFTA's first year, the effect of this treaty on enrollment was indeed very noticeable. In 1993, the year before this treaty began its implementation, there were 6,364 MBA students. A year later enrollment in these programs reached 9,834 students, an increase of 54.52 percent (ANUIES 2000). In subsequent years the rate of growth of enrollment leveled off at $13 \%$ per year. Thus by 2001, seven years into NAFTA, there were more than 24,000 MBA students distributed among 91 programs; 59 of these were offered by private schools and 32 by state universities (ANUIES 2002). These numbers suggest that, as expected, NAFTA and related policies have provoked a vigorous expansion in enrollment and in the number of programs. However, for an export-oriented economy with a $\$ 600$ billion GDP that, macroeconomically, has undergone a drastic modernization, this enrollment is still miniscule.

Miniscule has also been the influence of NAFTA and related policies on the quality of the MBA programs. According to: three senior professors from the IPADE, a professor from the Universidad de las Americas-Puebla, the UDLA, and to the director of the MBA program of the Universidad Iberoamericana, the UIA, the academic rigorousness of the programs has not experienced major changes in the last seven years. They also stated that regarding academic quality, now, as right before NAFTA, Mexico's MBA programs could be divided into three very distinct groups.

The IPADE, the Instituto Tecnológico Autónomo de México, the ITAM, and the full-time MBA program of the ITESM campus Monterrey would form the first group. Currently, as before NAFTA, these are the only programs where full time professors outnumber adjunct faculty. The ITAM has the added distinction of being the only pro- 
gram where most of the full-time professors have advanced degrees in business related areas from top American universities (ITAM 2002). Research is important in the IPADE (case development) and in the ITAM (it has its own journal). In the ITESM research is also supposed to be important, but neither the ITESM's web page nor the interviewed faculty mentioned anything about research activities in this institution (ITESM 2002).

Although not mentioned by the faculty interviewed, the Duxx School of Business should also be included in this first group. This school was established in Monterrey in 1998 by Pulsar, a conglomerate of the same city, as a response to the need for innovative managers created by the transformation of Mexico's economy. The Duxx MBA is a one-year full time program; all of its lecturers are invited professors from very prestigious American and European institutions; English is the official language of instruction, and it has an enrollment of 28 students. Like the other programs in this first group, its tuition exceeds $\$ 22,000$ per year (Duxx 2002).

The second group is formed by the programs offered by the UIA, the Universidad Anáhuac, the UDLA, and by the campuses of the ITSEM in Mexico City and Guadalajara. In these schools, today as before NAFTA, research is totally neglected. Adjunct professors, who usually lack advanced degrees, form the faculty. Some of these professors, however, are high-ranking executives in the private sector. Tuition in these schools is at least $\$ 4,000$ per semester which puts these programs out of the reach of many students (ANUIES 2002).

The third group includes the remaining private programs and all the MBAs offered by public universities. Adjunct professors form the faculty. These professors rarely have more than a bachelor's degree and are usually low ranking executives or government officials. Research, like in the second group, is non-existent. Tuition in this group rarely exceeds $\$ 3,000$ per semester in the private schools and $\$ 1,000$ per semester in the public universities (ANUIES 2002)

According to the faculty interviewed, NAFTA and other trade pacts signed by Mexico will continue transforming the economy, and hence, the enrollment in the MBA programs will also continue to grow. However, they do not expect to see an enrollment that would be commensurate with the size of Mexico's economy in the foreseeable future. Nor do they expect to see an across the board increase in the academic standards of these programs, especially if this increase is measured by the standards of organizations like the American Association of Collegiate Schools of Business, the AACSB.

\section{Possible Causes for the Small Enrollment and Stagnation in Academic Standards}

A low demand for academically qualified managers is, according to the interviewed faculty, the cause of the small enrollment in MBA programs and of the low academic standards of these programs. The professors interviewed stated that this low demand has persisted because the NAFTA driven transformation of the Mexican economy has not displaced large firms, especially large Mexican firms, from their privileged position in consumer and labor markets.

Previous to NAFTA, due to stiff import restrictions and an excessively regulated economy, a few large conglomerates dominated most consumer markets. Today, most import restrictions are gone and the regulations have been lessened. Yet, through the formation of alliances, the lobbying of high ranking government officials and the preservation of a few key regulations, seven years after NAFTA, a few conglomerates are still in a very privileged position in Mexico's most important consumer markets. Telecommunications, media, beer, corn flour, soft drinks, tortillas, steel, department stores, food retailing, and banks are sectors that continue to be dominated by monopolies or duopolies (Lunhow 2001).

For decades industrial inputs like energy were subsidized and huge labor surpluses kept wages very low. Today, subsidies are history and labor surpluses have shrunk considerable. Yet, the NAFTA driven expansion has not been vigorous enough to place the demand ahead of the supply in most labor markets. Thus wages, especially for blue collar workers, continue to be very low, approximately $\$ 1.75$ per hour (Vargas 1999). So, labor continues to be a very cheap, and thus expendable, resource. 
As mentioned above, Mexico's economy collapsed in 1982 because there were not enough dollars in the country to pay the interest on the foreign debt. To pay this debt and to buy a growing amount of imports, Mexico needed to generate growing amounts of dollars. This could only happen if Mexico's exports grew rapidly and steadily. Through NAFTA this growth has been accomplished. Exports of manufactured goods went from $\$ 40$ billion in 1993 to $\$ 130$ billion in 1999 (Friedland and Ducekerman 2000) Mexican firms, however, had contributed very little to this growth. Foreign firms that employ cheap Mexican labor produce well over 90\% of these exports (Vargas 1998).

So, seven years after NAFTA began its implementation, competition is still weak or non-existent in several of the most important consumer markets. Thanks to NAFTA, Mexican firms have never felt the need to export. Subsidies have been eliminated but labor, a crucial input in the production of goods and services, continues to be very cheap. In this environment few firms have the need to form their managerial ranks with individuals who have gone through the selection and rigorous academic training that good MBA programs are supposed to provide. In this environment, therefore, the demand for MBA graduates is not in proportion to the size of the economy.

The low demand for MBA graduates also contributes to the low academic standards that afflict most of the MBA programs. The faculty interviewed stated that the IPADE, the ITESM at Monterrey, and the ITAM have the best MBA programs in the nation. A primary reason for the superiority of these schools is their tuitions: tuitions that exceed $\$ 22,000$ per year and that allow them to hire very good faculty. This suggests that other schools could increase the quality of their programs by raising their tuitions to about $\$ 22,000$ per year. The director of the MBA at the UIA indicated that this, however, is not going to happen in the foreseeable future. According to this director, for most students the benefits that the MBA degree generates will not be enough to recover an investment that, in tuition alone, would be no less than $\$ 44,000$. To recover this investment, the income of MBA graduates would have to undergo very marked increases. But such increases could only occur if the demand for MBA graduates also undergoes marked increases. That is, by restricting the income of MBA graduates, the miniscule demand for them severely limits the ability of the MBA programs to raise their academic standards.

A cultural factor also contributes to the low academic standards. In Mexico, as in all Spanish-speaking countries, there is the firm belief that practitioners are better university professors than $\mathrm{Ph}$. Ds engaged exclusively in academic activities. In the case of the MBA programs, this means that executives who teach an evening class are considered better instructors than full time professors who have a Ph. D. in business related areas and whose job is to teach and to do academic research. The basis of this belief is that the executive, by virtue of his practical experience, brings more relevant knowledge to the classroom than the $\mathrm{Ph} \mathrm{D}$ whose knowledge is entirely theoretical.

To support this argument the director of the UIA's MBA program, who happens to have a Ph D from Stanford, stated that "If I were to undergo surgery, I would much rather have the doctor who has done many surgeries than the doctor who has great theoretical knowledge, but who has never operated in anybody." The interviewed professors from the IPADE indicated that there are two facts that severely weaken the validity of this view.

First, in Mexico, like in other countries, high-ranking executives rarely have enough time to do all they are supposed to do in their day jobs. This implies that the great majority of the executives who teach come from the lower ranks. Therefore, the work experience of most adjunct professors tends to be narrow and of little relevance for the formation of future executives.

Second, even low ranking executives face serious restrictions in the amount of time that they can devote to their academic duties. This restriction harms the quality of the lectures and weakens the rigorousness of exams and assignments.

The interviewed professors are convinced that the NAFTA driven modernization of the economy will induce a steady, albeit very slow, enhancement of the academic standards of the nation's MBA programs. They argued, however, that it is and will continue to be erroneous to measure the quality of these programs by the standards of organizations like the AACSB. According to them, the AACSB puts too much emphasis on the degrees and publications of the professors, and it neglects measuring the practical relevance of the professors' publications, the time 
after graduation that it takes new MBAs to find jobs in their fields, and how successful the professors have been in real business situations. If these neglected factors were taken into account while the emphasis in academic credentials was reduced, the interviewed faculty argued, the quality of several Mexican MBA programs would increase. In fact, they argued, the programs at the IPADE, ITAM and ITESM campus Monterrey, would be comparable to prestigious American programs; while the programs at the UIA, Universidad Anáhuac, UDLA, and ITESM's Guadalajara and Mexico City campuses, would be found to be of a quality that is very similar to the quality of the average accredited American MBA program.

\section{Implications for Foreign Executives Who Do Business in Mexico}

Before NAFTA one of the characteristics of Mexico's productive apparatus was the use of obsolete technology. This has changed radically. The use of modern technologies has become the rule rather than the exception across sectors and across firms. This change and the exporting nature of Mexico's economy could send the message that Mexico's business culture has also been modernized. This, however, is not correct.

As mentioned above, the NAFTA driven transformation of the economy has not created the economic conditions that would induce many firms to include MBAs in upper management. The relative absence of MBAs in top management combined with the dominance of the family firm suggest that NAFTA and accompanying policies have not provoked major changes in Mexico's business culture (The Economist 1997). Thus, foreign executives doing business with Mexican firms should be prepared to deal with traditions such as: excessive centralization of authority, decisions based upon inside information and the vision of the owner not upon detailed business analysis, lack of separation between ownership and management in firms of all sizes, promotions based on family kinship rather than on merits, and a slow decision making process.

The resilience of these and other traditions that may suggest inefficiency do not imply that the owner managers of Mexican firms are unsophisticated businessmen. These owner managers have survived very volatile macroeconomic conditions, conditions that are not analyzed in the typical MBA courses. So, despite the relative absence of MBAs in Mexican firms, it would be a mistake to underestimate the business knowledge of the owner managers of these firms.

\section{Conclusions}

In 1993, the year before NAFTA started and 26 years after the first MBA program was established, there were 6,364 MBA students. By 2001 enrollment in these programs had almost quadrupled, reaching a total of 24,000 students. Clearly, the modernization, growth, and economic stability generated by this treaty and accompanying policies have markedly increased the demand for managers with formal academic training. This drastic growth of the demand for MBAs has occurred even though NAFTA and related policies have yet to create an economy where the consumer is at the center, and where labor is relatively expensive. When this happens, the academic standards of the programs will rise and enrollment will be in proportion to the size of Mexico's economy.

\section{References}

1. $\quad$ ANUIES (1981). Anuario Estadístico 1980. México, D.F.

2. $\quad$ ANUIES (1982). Anuario Estadístico 1981. México, D.F.

3. ANUIES (2000). Población Escolar de Posgrado Anuario Estadístico 1999. México, D.F.

4. $\quad$ ANUIES (2001). Población Escolar de Posgrado Anuario Estadístico 2000. México, D.F.

5. $\quad$ ANUIES (2002) www.anuies.mx accessed 24 January 2002.

6. $\quad$ Duxx School of Business www.duxx.mx accessed 25 January 2002.

7. The Economist (1997 December $6^{\text {th }}-12^{\text {th }}$ ) Survey: Business in Latin America. pp. 3-26.

8. Friedland, J. \& Duckerman, P. (2000, August 3). Mexico gets coveted investment-grade rating. Wall Street Journal, p. A14.

9. IPADE www.ipade.mx accessed 24 January 2002.

10. ITAM www.itam.mx accessed 25 January 2002. 
11. ITESM www.itesm.mx accessed 25 January 2002.

12. Lunhow, D. (2001, February 21). Tale of Televisa: A Mexican Tug of War. Wall Street Journal, p. A16.

13. Vargas, L. (1998). The Maquiladora Industry in Historical Perspective. Federal Reserve Bank of Dallas. Business Frontier 3, pp. 1-4.

14. Vargas, L. (1999). NAFTA's First Five Years (Part 1). Federal Reserve Bank of Dallas. Business Frontier 2, p.2.

Notes 